\title{
Study on Cereal-Legume Based Complementary Foods for Infants
}

\author{
A. Siva Shankar ${ }^{1 *}$, Ch.V.V. Satyanarayana ${ }^{2}$, Sajid Alavi ${ }^{3}$, L. Edukondalu ${ }^{1}$, \\ Michael Joseph ${ }^{4}$ and R. Lakshmipathy ${ }^{5}$
}

${ }^{1}$ College of Agricultural Engineering, Bapatla, India

${ }^{2}$ College of Food Science \& Technology, Bapatla, India

${ }^{3}$ Kansas State University, Manhattan, KS, USA

${ }^{4}$ Tufts University, Boston, MA, USA

${ }^{5}$ Advanced PG centre Lam, Guntur, India

*Corresponding author

\section{A B S T R A C T}

\begin{tabular}{|l|}
\hline Ke y w o r d s \\
$\begin{array}{l}\text { Complementary } \\
\text { foods, Malnutrition, } \\
\text { Sugar, Infants, Food } \\
\text { formulation }\end{array}$ \\
\hline Article Info \\
\hline $\begin{array}{l}\text { Accepted: } \\
\text { 20 July } 2018 \\
\text { Available Online: } \\
10 \text { August } 2018\end{array}$ \\
\hline
\end{tabular}

Malnutrition is still public health problem in some parts of the world and causes irreversible damage at infant stage. Infants require high energy and nutrient dense foods because of their high growth velocity. Feeding fortified complementary blended foods is one of the options to treat malnourished infants. These foods are prepared with cereallegume blend, oil, sugar, vitamin/minerals and animal source protein. Complementary foods with high sugar content $(>15 \%)$ are not recommended to treat malnourished group. Animal source protein in complementary foods leads to hike in production cost. The purpose of this paper was to study the complementary foods for infants to make alternative inexpensive product formulation with low added sugar. Market survey was conducted on existing cereal-legume based foods for infants. Based on ingredients composition, products were short listed and a food formulation was selected to make an alternative. Kansas State University developed Corn-Soy blend and Sorghum-Soy blends, advanced versions in complementary foods were considered as control in this study for formulating an alternative composition. Complementary food with inexpensive plant source protein and sugar content less than $10 \%$ was recommended to meet nutrient density.

\section{Introduction}

Malnutrition could be related to a complexity of factors, causing inadequate feeding practices during the most vulnerable period of life, the weaning period, the age between 6 and 24 months in which the infant changes from breast-feeding to the family meal. It can categorise to be under-nutrition and overnutrition. Undernourishment to children is the curse for the future generation as they are not efficient in workforce. Infants and young children are especially vulnerable to undernourishment because they have a high growth velocity and also high energy and nutrient needs.

Growth velocity up to the age of about 2 years is especially high; during this period brain development reaches almost $90 \%$ of adult size. Nutrient requirements are also often proportionally greater for children than for 
adults, making it important to consume diets of high nutritional quality (Ebbeling et al., 2002).

For any food product development, many factors affect its preference and acceptability. Some factors are intrinsic to the product, such as physical, textural, sensory and other factors are extrinsic, such as social and cultural factors. Marketing studies regarding the determinants of food consumption have consistently shown that consumer choices are largely determined by taste (Drewnowski, 1997). In developing complementary foods, strategies to improve the consistency and energy density include; i) modification of the dry matter composition by malting and fermentation (Devi et al., 2014; Gernah et al., 2012); ii) addition of sugar and oil (de Pee, 2009); iii) chemical and enzymatic starch modification; and iv) extrusion cooking (Hoan et al., 2010).

Complementary or weaning foods are generally fortified to treat malnourished children. Such fortified complementary foods are simply mentioned as fortified blended foods (FBFs) in this study. FBFs are a combination of binary blends of cereals and legumes, with oil along with added sugar, vitamin/mineral premix and a possible source of milk based protein in it. The grains and legumes should be partially precooked in order to boost their digestibility, denature antinutritional factors, and reduce the cooking time required (Wood et al., 2008).

In many commercial food products, the manufacturers add extra ingredients to minimize the price but it affects the quality of the product. At best, these extra ingredients are nutritionally empty, and at worst, they are nutritionally dangerous, particularly when consumed by infants (Mishra and Dwivedi, 2015). For instance, many FBFs are high in sugar. Every calorie taken up by these ingredients is a lost opportunity for infant to eat a nutrient rich food that will facilitate proper growth and development. Studies from high-income countries have shown that a high sugar intake (above 15\%) has a negative influence on certain important nutrients, such as zinc, where the nutrient density was below the recommended level. In United Kingdom, the food industry, including retailers, manufacturers, restaurants and cafes has been challenged to cut 20 per cent of sugar from a range of products by 2020 from 2016 (G. Smith, UK, Newsletter (New Food)). In 2003, the report of a joint World Health Organization (WHO) / Food and Agriculture Organization (FAO) expert consultation on diet, nutrition and prevention of chronic diseases recommended that added sugar intake should not go above $10 \%$ at the population level. Breast milk contains less than $10 \%$ sugars (Lactose). Infants perceive about $75 \%$ nutritional requirements from breast milk and rest of the nutrition adopted through FBFs gradually from the age of above 6 months. Giving a FBF with high sugar content over a long period may make it difficult for the child later to accept a diet with no or very low sugar content. The amount of sugar should generally not exceed $10 \%$ in FBFs, although $20 \%$ for up to a few weeks may be acceptable for treatment of wasted children (Michaelsen et al., 2009).

Pricing is the major concern for food manufacturers. Hence, additional sugar is added to compensate the energy requirements from cereal-legume blend and also to achieve flow requirements of the FBF for infants in stipulated conditions. FBFs produced in the United States of America have to meet the requirements from the United States Department of Agriculture (USDA), while the locally produced FBFs are controlled by organizations such as the World Food Program (WFP) and United Nations Children's Fund (UNICEF). Another predominant factor 
to influence price of product is protein source used in the product. This problem can be tackled by utilising locally available and low cost raw materials such as corn, sorghum and soybean. Growers will be benefitted by value addition to their produce consistently. Production of FBFs from locally available materials would result affordable cost of product. Keeping in view of above facts a survey was conducted on commercially available complementary foods for infants to formulate $\mathrm{FBF}$.

\section{Materials and Methods}

Market survey was conducted to select appropriate FBF as control sample (Fig.1). Recent reports asserted that malnutrition in infant stage is crucial and still there is a need to do research with locally available raw materials. The number of chronically undernourished people in the world is estimated to have increased to 815 million, up from 777 million in 2015 although still down from about 900 million in 2000 (FAO et al., 2017).

A survey was conducted in Bapatla town, Adilabad and Bhopal surroundings (Andhra Pradesh, Telangana and Madhya Pradesh states of India respectively. Collected information about existing FBFs distributed for infants and their ingredients by visiting local market, Anganwadi centres (Rural mother, child care and feeding centres funded by local Government) and households. Public distribution foods [Integrated Child Development Scheme (ICDS) India, WFP and United States Agency for International Development (USAID)] and previous research works related to FBFs were also considered in this study. Nutritional and ingredients information was noted from product labels of existing FBFs and made a list of products. Ingredients in existing FBFs were identified to arrive at optimum nutritional structure of product. Short listed product specifications were considered as the base for new product formulation. Product formulation was prepared manually. Processing cost has been found to vary with technology adopted for production. Therefore, cost comparison is difficult to maintain. However, ingredients proportion in production was considered to shortlist the complementary foods, and also suitable technologies were discussed for production of cost effective alternative complementary food.

\section{Results and Discussion}

Market survey on FBFs for infants gave an idea about existing products (Table 1). The complementary food market in India was highly organized and predominantly dominated by a single player, Nestle. Other major players operating in India include Abbott Nutrition, Nutricia, Raptakos, Amul, Pristine Organics, British Life Sciences, Mead Johnson, Babyvita and Manna Foods. Nestle branded baby foods contain on average $28 \%$ animal source protein (skim milk powder) and 9\% added sugar and are well accepted (Kampstra et al., 2017).

Developing and under developed countries are the potential destination for complementary food manufacturers with huge untapped market. Commercial complementary foods were expensive because of import and handling costs in addition to production cost. Public distribution program foods were alternative source for economically backward family children. Production of weaning foods from locally available and low cost raw materials such as cereals and legumes was recommended by the ICDS and FAO to overcome the malnutrition among children in under developed and developing countries (Satter et al., 2013). However, technology adopted for production also makes difference in product safety and cost. Soybean is an 
inexpensive plant source of protein whose protein quality is considered equivalent to animal protein (FAO, 1991). Addition of soybean can act as a good source of protein in formulated food products besides offering other functional, nutritional and health benefits (Friedman and Brandon, 2001).

GAIN (Global alliance for improved nutrition) developed a FBF named Balamrutham distributed in India and was well accepted product. USAID and WFP distributed products such as CSB+ (Corn Soy Blend Plus, non-extruded product) and super cereal plus (extruded product) are popular in low income countries. CSB14 (Corn Soy Blend $14^{\text {th }}$ edition) and SSB14 (Sorghum Soy Blend $14^{\text {th }}$ edition) were developed by Kansas State University and implemented in MFFAPP (Micronutrient Fortified Food Aid Products Pilot) program, Tanzania (Joseph, 2016).

Traditional complementary foods like Uggu, Sattu, Gatka and Ragi malt are giving healthy competition to commercial products. These traditional products are made with locally grown produce and easy to prepare at home. But these foods have low energy density compared to commercially available complementary foods.

Based on the market survey, commercially viable cereal-legume based complementary foods to mitigate malnutrition were identified. CSB+ is one of the most valuable FBFs extensively distributed food material in USAID programs (USDA, 2014). Balamrutham (non-extruded) was widely distributed FBF in Andhra Pradesh and Telangana states of India in ICDS program.

Various food processing techniques are in use for preparation of complementary foods like extrusion process and conventional processes including germination, roasting, milling, baking, cooking, drying and fermentation. Extrusion process is a contemporary food processing technology to produce wide variety of foods and products that are microbial safe because it is a high temperature and shot time process and extrusion process is best suited for large scale production and leaves no effluents.

Fig.1 Markey survey plan

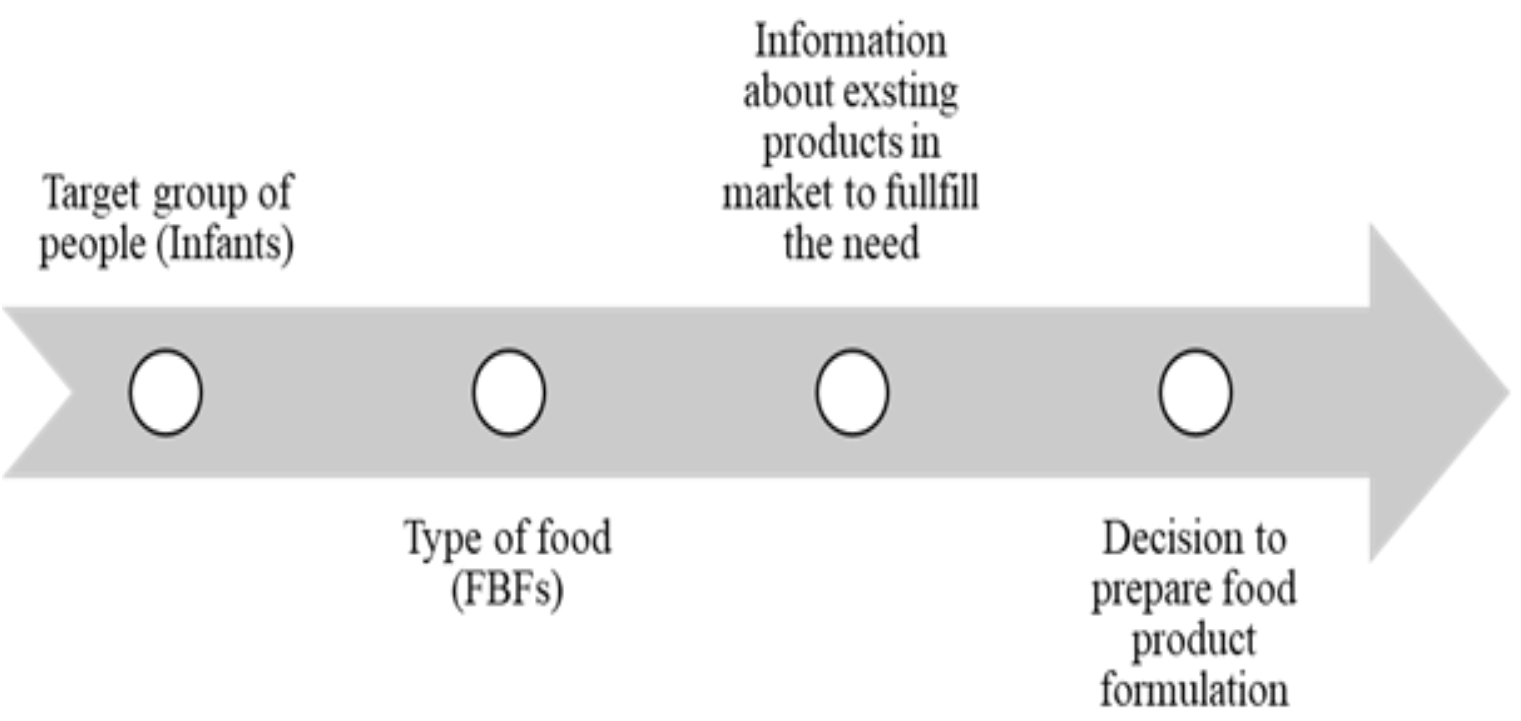


Table.1 Cereal-Legume based complementary foods for infants

\begin{tabular}{|c|c|c|c|}
\hline Product & Source & Major ingredients \% & $\begin{array}{l}\text { Processing } \\
\text { technique }\end{array}$ \\
\hline $\begin{array}{c}\text { Nestle Cerelac } \\
\text { Fortified Baby Meal } \\
\text { with Milk Wheat }\end{array}$ & Nestle & $\begin{array}{l}\text { Wheat flour (48.3), milk solids ( } 32.9) \text {, sugar } \\
\text { (11.8), soybean oil and vitamins and minerals }\end{array}$ & Roasting \\
\hline Farex rice & Farex & $\begin{array}{l}\text { Milk solids (41.5), rice flour (40.5), soy oil and } \\
\text { minerals }\end{array}$ & Roasting \\
\hline Balamrutham & ICDS in India & $\begin{array}{c}\text { Roasted Wheat (55), Bengal Gram (5), } \\
\text { Skimmed Milk Powder (10), Sugar (20) and Oil } \\
\text { (10) }\end{array}$ & Roasting \\
\hline $\begin{array}{l}\text { Sorghum soy blend } \\
\text { (SSB14) }\end{array}$ & $\begin{array}{l}\text { MFFAPP* in } \\
\text { Tanzania } \\
\text { (Joseph, 2016) }\end{array}$ & $\begin{array}{l}\text { Sorghum flour (63.4), soy flour (15), vegetable } \\
\text { oil (9), vitamin \& mineral premix (3.1), sugar } \\
\text { (15) and whey protein (9.5) }\end{array}$ & Extrusion \\
\hline $\begin{array}{l}\text { Corn soy blend } \\
\text { (CSB14) }\end{array}$ & $\begin{array}{l}\text { MFFAPP in } \\
\text { Tanzania } \\
\text { (Joseph, 2016) }\end{array}$ & $\begin{array}{l}\text { corn meal (63.4), soy flour (15), vegetable oil } \\
\text { (9), vitamin \& mineral premix (3.1), sugar (15) } \\
\text { and whey protein (9.5) }\end{array}$ & Extrusion \\
\hline $\begin{array}{l}\text { Sorghum cowpea } \\
\text { blend (SCB14) }\end{array}$ & $\begin{array}{l}\text { MFFAPP in } \\
\text { Tanzania } \\
\text { (Joseph, 2016) }\end{array}$ & $\begin{array}{l}\text { corn meal (63.4), soy flour (15), vegetable oil } \\
\text { (9), vitamin \& mineral premix (3.1), sugar (15) } \\
\text { and whey protein (9.5) }\end{array}$ & Extrusion \\
\hline $\begin{array}{l}\text { Corn-Soy blend } \\
\text { (CSB13) }\end{array}$ & USDA, 2008 & $\begin{array}{l}\text { Corn meal (69.55), soy flour, (21.85), vitamin } \\
\text { \& mineral premix (3.1) }\end{array}$ & Roasting \\
\hline Super cereal plus & WFP, 2015 & $\begin{array}{c}\text { Corn (58), soy flour (20), skimmed milk } \\
\text { powder (8), sugar (10), vegetable oil (3), and } \\
\text { vitamin \& mineral premix (1.7). }\end{array}$ & Extrusion \\
\hline CSB plus & USDA, 2014 & $\begin{array}{c}\text { Corn (78.47), Whole soybeans }(20) \text {, } \\
\text { Vitamin/Mineral }(0.20) \text {, Tri-Calcium Phosphate } \\
\text { (1.16), Potassium chloride }(0.17)\end{array}$ & Roasting \\
\hline $\begin{array}{l}\text { Protein enriched } \\
\text { sorghum malt }\end{array}$ & $\begin{array}{l}\text { Jiddere and } \\
\text { Filli, } 2015\end{array}$ & Sorghum malt \& bambara groundnut & $\begin{array}{l}\text { Malting and } \\
\text { extrusion }\end{array}$ \\
\hline $\begin{array}{c}\text { Micro nutrient } \\
\text { beverage powder }\end{array}$ & $\begin{array}{l}\text { Tripathi et al., } \\
2014\end{array}$ & $\begin{array}{l}\text { Malted finger millet (47), glucose (20), hibiscus } \\
\text { powder }(22) \text {, citric acid }(0.5) \text { and vanilla }(0.5)\end{array}$ & $\begin{array}{l}\text { Malting and } \\
\text { extrusion }\end{array}$ \\
\hline $\begin{array}{c}\text { Millet based } \\
\text { complementary food }\end{array}$ & $\begin{array}{l}\text { Devi et al., } \\
2014\end{array}$ & $\begin{array}{c}\text { Sorghum (50), rice (30), soybean (20) and } \\
\text { malted finger millet (15) }\end{array}$ & $\begin{array}{l}\text { Malting and } \\
\text { Extrusion }\end{array}$ \\
\hline $\begin{array}{c}\text { Health drink } \\
\text { powder } \\
\end{array}$ & $\begin{array}{l}\text { Kumar et al., } \\
2013\end{array}$ & $\begin{array}{l}\text { Malted finger millet, pulses \& skim milk } \\
\text { powder }\end{array}$ & Malting \\
\hline $\begin{array}{c}\text { Extrusion cooking of } \\
\text { pearl millet }\end{array}$ & $\begin{array}{l}\text { Sumathi et al., } \\
\quad 2007\end{array}$ & defatted soy flour \& pearl millet (70) & Extrusion \\
\hline $\begin{array}{l}\text { Pigeon pea based } \\
\text { weaning food }\end{array}$ & $\begin{array}{l}\text { Mohammed et } \\
\quad \text { al., } 2011\end{array}$ & Sorghum (65) and pigeon pea (35) & Drum drying \\
\hline$\overline{U g g u}$ & $\begin{array}{c}\text { Indian } \\
\text { Traditional food }\end{array}$ & $\begin{array}{c}\text { Rice (44), pigeon pea (22), (green gram (22) } \\
\text { and black gram (12) }\end{array}$ & Roasting \\
\hline Gatka & Traditional food & Malted sorghum and salt/sugar (non-fortified) & Fermentation \\
\hline Ragi malt & Traditional food & $\begin{array}{l}\text { Malted finger millet and salt/sugar (non- } \\
\text { fortified) }\end{array}$ & Fermentation \\
\hline
\end{tabular}

*Micronutrient Fortified Food Aid Products Pilot 
Table.2 Final composition of Corn-Soy blend

\begin{tabular}{|l|l|l|l|l|l|} 
& $\begin{array}{l}\text { CSB14 } \\
(\text { Control })\end{array}$ & $\begin{array}{l}\text { CSB* } \\
(\mathbf{0 \%} \text { sugar })\end{array}$ & $\begin{array}{l}\text { CSB } \\
(\mathbf{5 \%} \text { sugar })\end{array}$ & $\begin{array}{l}\text { CSB } \\
(\mathbf{1 0 \%} \text { sugar })\end{array}$ & $\begin{array}{l}\text { CSB } \\
(\mathbf{1 5 \%} \\
\text { sugar })\end{array}$ \\
\hline Corn flour & 48.4 & 55.9 & 49.9 & 43.9 & 37.9 \\
\hline $\begin{array}{l}\text { Defatted soy flour } \\
\text { Oil (\%) }\end{array}$ & 15.0 & 32.0 & 33.0 & 34.0 & 35.0 \\
\hline Vitamin premix (\%) & 9.0 & 9.0 & 9.0 & 9.0 & 9.0 \\
\hline Mineral premix (\%) & 0.1 & 3.0 & 3.0 & 3.0 & 3.0 \\
\hline Sugar (\%) & 0.1 & 0.1 & 0.1 & 0.1 \\
\hline Whey protein (\%) & 9.5 & - & -0 & 10.0 & 15.0 \\
\hline Total & $\mathbf{1 0 0 . 0}$ & $\mathbf{1 0 0 . 0}$ & $\mathbf{1 0 0 . 0}$ & $\mathbf{1 0 0 . 0}$ & $\mathbf{1 0 0 . 0}$ \\
\hline $\begin{array}{l}\text { Energy (kcal per 100 g) } \\
\text { *Corn-Soy Blend }\end{array}$ & $\mathbf{3 8 7 . 0 0}$ & $\mathbf{3 9 3 . 5 9}$ & $\mathbf{3 9 5 . 3 4}$ & $\mathbf{3 9 7 . 0 9}$ & $\mathbf{3 9 8 . 0 4}$ \\
\hline
\end{tabular}

Different variants of FBFs using extrusion technology were developed at Kansas State University (KSU) based on FAQR (Food Aid Quality Review) recommendations for public health distribution program. Recently developed FBFs contained animal source protein (WPC80, Whey Protein Concentrate $80 \%$ purity) and sugar to achieve viscosity within prescribed USDA standards of 9-21 $\mathrm{cm} / \mathrm{min}$. Products are well accepted in Tanzania (Joseph, 2016). However, there is a possibility to reduce the cost of product by replacing expensive WPC 80 with plant based protein sources such as soy protein. KSU developed FBFs named as CSB14 and SSB14 are advanced formulations than those developed under WFP and USAID. CSB+ and super cereal plus FBFs need to cook five to ten minutes to prepare porridge but CSB14 and SSB14 required only one-minute cooking.

Recent studies on protein quality and protein efficiencies of CSB14 and SSB14 were compared with $\mathrm{CSB}+$ via experiments on rats and broiler chickens. Results revealed these FBFs have higher protein quality and iron bioavailability compared to $\mathrm{CSB}+$ (Fiorentino et al., 2017). Also, field trials demonstrated the efficacy FBFs (CSB14 and SSB14) in combating micronutrient deficiencies and supporting linear growth in children (Delimont et al., 2017).

Keeping in view of above facts, CSB14 and SSB14 formulations were considered as control samples for reformulation. CSB14 and SSB14 formulations have 15\% sugar content and 9\% WPC 80 . Improved formulations with better nutritional and energy per unit serve prepared based on CSB14 as control (Table 2) were considered for further work of evaluation of flow properties.

Complementary foods to treat malnourished infants and children should be limited to addition of sugar less than $15 \%$. To improve energy and nutrient density of complementary foods, novel food processing technologies such as extrusion has to be adapted for traditional food formulations. Incorporation of underutilised crops in these foods leads to reduction of the cost of product. From the market study, new formulations were prepared for further improvement in existing product. These formulations are used to 
conduct experiments to evaluate effect of process variables on flow properties.

\section{Acknowledgment}

The authors would like to specially acknowledge Dr. Brian Lindshield, Associate Professor, Kansas State University, USA for nutritional formulation. We also thank to Dr. Saikath Datta Mazumdar, Chief Operating Officer, Nutriplus knowledge program, ICRISAT, Hyderabad, India.

\section{References}

De Pee, S and Bloem, M. W. 2009. Current and potential role of specially formulated foods and food supplements for preventing malnutrition among 6 to 23 month-old children and for treating moderate malnutrition among 6 to 59 month-old children. Food and Nutrition Bulletin. 30(3): 434-463.

Delimont, N. M., Fiorentino, N. M., OpokuAcheampong, A. B., Joseph, M. V., Qingbin Guo, O., Alavi, S and Lindshield B. L. 2017. Newly formulated, protein quality-enhanced, extruded sorghum-, cowpea-, corn-, soya-, sugar- and oilcontaining fortified-blended foods lead to adequate vitamin $\mathrm{A}$ and iron outcomes and improved growth compared with nonextruded CSB plus in rats. Journal of Nutritional Science. doi.10.1017/ jns.2017.15

Devi, N. L., Shobha, S., Alavi, S., Kalpana, K and Soumya, M. 2014. Utilization of extrusion technology for the development of millet based complementary foods. Journal of Food Science and Technology. 51(10): 2845-2850.

Drewnowski, A.1997. Taste preferences and food intake. Annual Review of Nutrition. 17:237-253.

Ebbeling, C. B., Pawlak, D. B and Ludwig, D. S. 2002. Childhood obesity: public health crisis, common sense cure. Lancet. 360(9331): 473-482.
FAO (Food and Agricultural Organization), IFAD (International Fund for Agricultural Development) and WFP (World Food Program). 2017. The State of Food Insecurity in the World 2017. www.fao.org/3/a-I7695e.pdf

FAO. 1991. Protein Quality Evaluation. Report of the Joint FAO/WHO Expert Consultation. www.who.int/iris/handle/10665/38133

Fiorentino, N. M., Kimmel, K. A., Joseph, M., Alavi, S., Beyer, R. S and Lindshield, B. L. 2017. Newly formulated fortified blended foods result in improved protein quality and iron bioavailability in broiler chickens. The Official Journal of Federation of American Societies for Experimental Biology. 31(1).

Friedman, M. and Brandon, D. L. 2001. Nutritional and Health Benefits of Soy Proteins. Journal of Agriculture and Food Chemistry. 49: 1069-1086.

Gernah, I. D., Ariahu, C. C. and Umeh, U. E. 2012. Physical and microbiological evaluation of food formulations from malted and fermented maize (Zea mays L.) fortified with defatted sesame (Sesamum indicum L.) flour. African Journal of Food Science and Technology. 4(3):148-154.

Hoan, N. V., Mouquet-River, C., EymardDuvernay, S. and Treche, S. 2010. Effects of extrusion cooking and amylase addition to gruels to increase energy density and nutrient intakes by Vietnamese infants. Asia Pacific Journal of Clinical Nutrition. 19(3): 308-315. http://www.fsa.usda.gov/Internet/FSA_Fil e/csb11.pdf

Jiddere, G and Filli, K. B. 2015. The effect of feed moisture and barrel temperature on the essential amino acids profile of sorghum malt and bambara groundnut based extrudates. Journal of Food Process Technology. 6: 448. doi: 10.4127/2157-7110.1000448

Joseph, M. V. 2016. Extrusion, physicochemical characterization and nutritional evaluation of sorghum-based high 
protein, micronutrient fortified blended foods. Ph.D. Thesis. Kansas State University, Manhattan, KS.

Kampstra, N. A., Hoan, N. V., Koenders, D. J. P. C., Schoop, R., Broersen, B.C., Mouquet Rivier, C., Traoré, T., Bruins, M. J and De Pee, S. 2017. Energy and nutrient intake increased by $47-67 \%$ when amylase was added to fortified blended foods - a study among 12 to 35 month old Burkinabe children. Maternal and Child Nutrition. doi.org/10.1111/ mcn.12459

Kumar, A., Goel, B. K., Karthikeyan, S., Asgar and Gedda, A. K. 2013. Protein and calcium rich malted health drink power. Journal of Food Process Technology. 4: 214.

Michaelsen, K. F., Hoppe, C., Roos, N., Kaestel, P., Stougaard, M., Lauritzen, L., Mølgaard, C., Girma, T and Friis, H. 2009. Choice of foods and ingredients for moderately malnourished children 6 months to 5 years of age. Food and Nutrition Bulletin. 30(3): S343-S404.

Mishra S, Dwivedi P. 2015. Safe baby food. Consumer Education Monographs. Series 17. http://consumeraffairs.nic.in/ WriteReadData/userfiles/file/Baby\%20Fo od.pdf

Mohammed, N. A., Mohammed, I. A and Barbiker, E. E, 2011. Nutritional evaluation of sorghum flour (Sorghum bicolour L. Moench) during processing of injera. International Journal of Biological Life Sciences. 7: 1.

Satter, M. A., Jabin, S. A., Abedin, N., Arzu, T., Mitra, K., Abdullah, A. M and Paul, D. K. 2013. Development of nutritionally enriched instant weaning food and its safety aspects. African Journal of Food Science.7: 238-245.

Sumathi. A., Usha, K. S. R and Malleshi, N. G. 2007. Physico-chemical characteristics, nutritional quality and shelf-life of pearl millet based extrusion cooked supplementary foods. International Journal of Food Science and Nutrition. 58 (5): 350-362.

Tripathi, J., Gupta, A and Puranik, P. V. 2014. Enhancing micronutrient content of beverage powder by incorporating malted finger millet. Indian Journal of Community Health. 26(2): 339-342.

USDA (United States Department of Agriculture). 2005. CSB11 Corn soy blends for use in export programs. U.S. Department of Agriculture Commodity Requirements.

USDA. 2008. USDA commodity requirements. CSB 13 Corn soy blend for use in export programs.

https://www.fsa.usda.gov/Internet/FSA_F ile/csb13.pdf

USDA. 2014. USDA Commodity requirements. CSB plus for use in export programs. https://www.fsa.usda.gov/Internet/FSA_F ile/csbp2.pdf

WFP. Super cereal plus commodity specifications. 2015 . http://foodqualityandsafety.wfp.org

Wood, J., Palazzo, M and Dijkhuizen, P. 2008. Fortified Blended Foods: From a Nutritional Objective to a Development Opportunity. The Contribution of WFP to the Production and Use of Blended Foods in Developing Countries. Report to WFP. Rome. Mimeo (original date 2006; Revised June 2008).

\section{How to cite this article:}

Siva Shankar, A., Ch.V.V. Satyanarayana, Sajid Alavi, L. Edukondalu, Michael Joseph and Lakshmipathy, R. 2018. Study on Cereal-Legume Based Complementary Foods for Infants. Int.J.Curr.Microbiol.App.Sci. 7(08): 3310-3317. doi: https://doi.org/10.20546/ijcmas.2018.708.354 